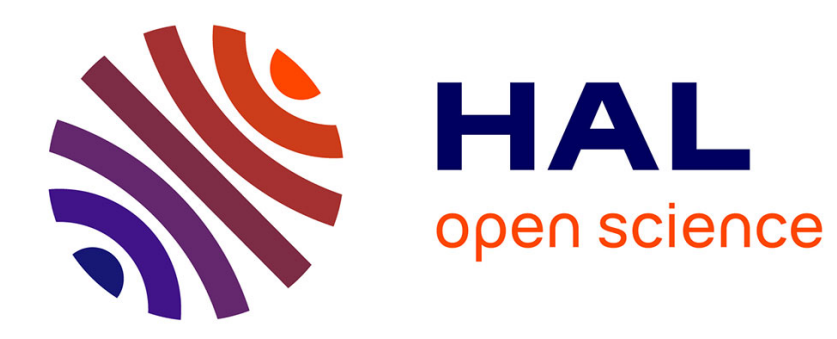

\title{
Emerson's Temporalities: The Eternal Present vs. the Not Yet Present
}

\author{
Danielle Follett
}

\section{To cite this version:}

Danielle Follett. Emerson's Temporalities: The Eternal Present vs. the Not Yet Present. 2019. hal-02317913

\section{HAL Id: hal-02317913 \\ https://hal.science/hal-02317913}

Preprint submitted on 16 Oct 2019

HAL is a multi-disciplinary open access archive for the deposit and dissemination of scientific research documents, whether they are published or not. The documents may come from teaching and research institutions in France or abroad, or from public or private research centers.
L'archive ouverte pluridisciplinaire HAL, est destinée au dépôt et à la diffusion de documents scientifiques de niveau recherche, publiés ou non, émanant des établissements d'enseignement et de recherche français ou étrangers, des laboratoires publics ou privés. 


\title{
Emerson's Temporalities: The Eternal Present vs. the Not Yet Present
}

\author{
Danielle Follett, Université Sorbonne Nouvelle
}

In "Experience," Emerson writes, "Our life seems not present, so much as prospective." Here and elsewhere he expresses an intuition of human and natural vitality as a process of becoming and a progression toward a glimpsable but not yet existent, more harmonious state. "Not for the affairs on which it is wasted," he continues, "but as a hint of this vast-flowing vigor" (CW 3:42). That is, our life hints toward the eventual manifestation of the "unbounded substance" - one of his many terms for the divine power - mentioned a few lines earlier. Emerson describes a hopeful path, a "tendency or direction," toward the future realization of something higher that is intimated but not yet actual (CW 3:42). "Life is hereby melted into an expectation or a religion" (CW 3:41).

However, just before and after these passages, and elsewhere in his writings, Emerson also maintains that this ultimate power is always already present in the here and now, and in all our actions: "Every day, every act betrays the ill-concealed deity" (CW 3:45). Underlying and omnipresent, the divine energy not only invests every day and every moment with its immanent force, but it also isolates the present moment from all others, extracting it from linear time, creating a highly charged eternal present: "God delights to isolate us every day, and hide from us the past and the future" (CW 3:39). We are not invited to orient ouselves prospectively towards the future, but rather to experience fully the heightened moment: "'You will not remember,' he seems to say, 'and you will not expect"' (CW 3:39). The charged present instant is self-contained and specifically denies any connection to past or future. Paradoxically, for Emerson, being's grandeur is both yet to come and forever underlying the flux of multiplicity; it is both future and eternally present.

We thus have the juxtaposition of two quite different temporalities: the linear, progressive, teleological temporality of a movement toward a higher state that is heralded but not yet existent; and the instantaneous, spontaneous temporality of heightened spiritual experience manifesting itself in an unending series of present moments, which reject before and after but open onto eternity. This coexistence is witnessed not only in "Experience" but throughout Emerson's writings. What are the relationships between these two temporalities? Can we draw a larger circle around this apparent contradiction, or is this an example of an unresolved or irreducible instability? This article will explore these questions, and argue that the discrepancy between these divergent views of time participates in a fundamental metaphysical tension that informs Emerson's thought.

These issues may only be understood in the light of Emerson's complex spiritual perspectives. A detranscendentalizing critical approach necessarily misses certain metaphysical and religious elements which help explain and contextualize the tensions and paradoxes evident in Emerson's conflicting conceptions of time. ${ }^{2}$ Indeed, both of Emerson's temporalities are fundamentally metaphysical and spiritual, though in quite different ways, and it does not make sense to speak of a secular temporality in Emerson. Emerson's thought and philosophy in general are rooted in his lifelong heterodox religious and metaphysical explorations as well as those of his intellectual circle, and cannot be comprehended outside of this context. The detranscendentalizing view of Emerson and other transcendentalists arose during the poststructuralist period, marked by its generally skeptical and anti-metaphysical critical attitude, and has taken the form of analyses that tend to minimize, sideline or negate 
the religious and metaphysical foundations of transcendentalist thought. ${ }^{3}$ George Kateb, struggling to read Emerson as a secular thinker in his Emerson and Self-Reliance, admitted frankly, "It is obvious that I find the religiousness of Emerson an impediment to my reception. ... [T] he fact of pervasive religiousness remains a tremendous problem." As Lawrence Buell observed in Emerson in 2003, "Reluctance to imagine Emerson as a religious thinker has lately intensified," but "[t]here is simply no way to ignore the centrality of the religious to the thinking of [this] ex-minister." 5 His chapter entitled "Religious Radicalisms" constitutes an attempt to reestablish the importance of Emerson's religiosity. Around the same time, David Robinson devoted two articles to the religious aspects of Emerson's philosophy (2000, 2003), Yves Carlet reminded French readers not to forget the spiritual character of transcendentalism (2003), and Daniel S. Malachuk strongly criticized the detranscendentalizing critical approach (2004-2005). ${ }^{6}$ Since then, a handful of studies have appeared that foreground Emerson's metaphysical and religious concerns. In 2007, Randy L. Friedman argued similarly that "it is difficult to ignore the religiosity of [Emerson's] thought," and placed the concept of self-reliance in a metaphysical rather than secular tradition; his 2012 article "Religious Self-Reliance" reads Emerson as a philosopher of religion. ${ }^{7}$ Robert Milder's two articles in The New England Quarterly $(2007,2014)$ are accounts of Emerson's evolving spiritual views, focusing respectively on what Milder considers (problematically, I believe) Emerson's late Calvinism and his "Godless religion." 8 Neal Dolan's Emerson's Liberalism (2009) founds his analysis of Emerson's liberalism on metaphysical concepts such as universal moral law. ${ }^{9}$ Mark S. Cladis and Shira Wolosky each devoted an article to Emerson's religious perspectives in the journal Religion and Literature in 2009. ${ }^{10}$ In 2010, Russell B. Goodman analyzed Emerson's essay on nominalism and realism in terms of its metaphysical significance; his earlier works on Emerson also bring a metaphysical perspective to the debate and constitute an exception to the general detranscendentalizing effort of the period. ${ }^{11}$ Daniel S. Malachuk's excellent 2011 article "Emerson's Politics, Retranscendentalized" and 2016 Two Cities: The Political Thought of American Transcendentalism demonstrate the centrality of spirituality and metaphysics to Emerson's political thought. ${ }^{12}$ Alan M. Levine showed that contrary to the detranscendentalizers' assertions, Emerson is ultimately not a Nietzschean skeptic but resolutely affirmative of the divine power (2011). ${ }^{13}$ Samantha Harvey's insightful analyses of Coleridge's and Emerson's philosophies of nature are sensitive to metaphysical issues (2013). ${ }^{14}$ My 2015 article analyzes Emerson's immanentist metaphysics and the dissonances created within it by his occasional dualism. ${ }^{15}$ Finally, Joseph Urbas's important series of articles $(2009,2010,2013)$ and his groundbreaking Emerson's Metaphysics: A Song of Laws and Causes (2016) argue in convincing detail that Emerson's philosophy is fundamentally a spiritual ontology whose first principle is causation, and which grew out of the metaphysical concerns of his time. ${ }^{16}$

In keeping with the "retranscendentalizing" bent of these studies, I will claim that Emerson's conceptions of time are rooted in his religious and metaphysical views and reflect their complexity. It would be difficult to detranscendentalize such statements as "The present hour is the descending God." ${ }^{17}$ Emerson was a syncretistic spiritual thinker, and his different conceptions of time are rooted in his various philosophical and religious influences, which when brought together do not always fully cohere. Clearly, the linear, progressive temporality is related to Emerson's view of history as advancing toward a greater future, a view anchored in his background and his century. The general Protestant eschatological sense of time combines in Unitarianism with an Enlightenment scientific progressivism, which is reinforced in Emerson's early readings by Scottish common-sense rationalism and overlaid with a teleological sense of biological evolution, creating a syncretic progressivism. This 
perspective is helpfully summarized by Neal Dolan, who writes: "one of the most striking features of Emerson's work from [1833] forward is the way he folds a conception of inexorable human progress into the larger evolutionary flow of cosmic deep time." 18 Expressions of this view abound in Emerson's writings; for example we see it in "The Poet" in the term "ascension," which carries both biological and spiritual meanings: "But nature has a higher end, in the production of new individuals, than security, namely, ascension, or, the passage of the soul into higher forms" (CW 3:14). It is reflected on a social level in the optimistic exhortations given in "The Young American":

"Remark the unceasing effort throughout nature at somewhat better than the actual creatures: amelioration in nature, which alone permits and authorizes amelioration in mankind. The population of the world is a conditional population; these are not the best, but the best that could live in the existing state of soils, of gases, animals and morals: the best that could yet live; there shall be a better, please God" (CW 1:230231).

We see a similar expression of teleological metamorphosis and progressive evolutionary time in the second epigraph to Nature: "And, striving to be man, the worm / Mounts through all the spires of form" (CW 1:7). The progressive temporality often takes the form of hope and expectation. In his "Introductory Lecture" to the series "Lectures on the Times," Emerson speaks of the "promise" and "tendency" of the times, or its directionality: "Let us not inhabit times of wonderful and various promise without once divining their tendency" (CW 1:171). The eschatological perspective clearly appears in "the Transcendentalist":

"Our American literature and spiritual history are, we confess, in the optative mood ... I know that which shall come will cheer me.... Patience, then, is for us, is it not? Patience, and still patience. ... presently we shall [pass] into some new infinitude, out of this Iceland of negations" (CW 1:207, 212, 214).

The entreaty for patience recalls "The American Scholar": "Patience-patience; —with the shades of all the good and great for company; and for solace, the perspective of your own infinite life ... A nation of men will for the first time exist, because each believes himself inspired by the Divine Soul which also inspires all men." (CW 1:69, 70). And this brings us back to "Experience": "Patience and patience, we shall win at the last" (CW 3:48-49). One of Emerson's moods is certainly, as he says, optative.

On the other hand, the temporality of the infinite moment, the "everlasting Now," partakes in the enthusiastic tradition of divine immanence within the visionary subject and within the world, as well as the romantic epiphanic tradition and valorization of the ordinary and the everyday. ${ }^{19}$ The highest spiritual force invests the "lowest" and most common experience, from Blake's "Eternity in an hour" ("Auguries of Innocence") through Wordsworth's and Coleridge's celebrations of the spiritual import of everyday experiences, to Emerson's moment as a transparent eyeball, crossing the "bare common" (CW 1:10). ${ }^{20} \mathrm{He}$ writes in "The Oversoul":

But the soul that ascends to worship the great God... dwells in the hour that now is, in the earnest experience of the common day, - by reason of the present moment and the mere trifle having become porous to thought and bibulous of the sea of light. ... The universe is represented in an atom, in a moment of time (CW 2:172, 175). 
In the minutest measure of time ("the hour that now is," "the common day,") and the most ordinary objects ("the bare common," "the mere trifle," "an atom"), the infinite and eternal is manifested. Whereas in his analysis of Emerson's philosophy Stanley Cavell both focuses on the concept of the everyday and simultaneously disparages metaphysics as "empty," for Emerson at least, the everyday is an eminently metaphysical concept. ${ }^{21}$ Far from representing the negation of the metaphysical concept of eternity, the value of the ordinary moment is for him precisely its capacity to contain eternity. Similarly, the significance of the most common or everyday objects and experiences is that they may be invested with an uncommon or extraordinary (divine) power. The everyday contains "the highest spiritual cause," as he states in "The American Scholar":

I embrace the common, I explore and sit at the feet of the familiar, the low. Give me insight into to-day, and you may have the antique and future worlds. ... show me the sublime presence of the highest spiritual cause lurking, as always it does lurk, in these suburbs and extremities of nature; let me see every trifle bristling with the polarity that ranges it instantly on an eternal law; and the shop, the plough, and the leger, referred to the like cause by which light undulates and poets sing;- - and the world lies no longer a dull miscellany and lumber room, but has form and order; there is no trifle; there is no puzzle; but one design unites and animates the farthest pinnacle and the lowest trench (CW 1:67-68).

The common, low, ordinary and everyday are for Emerson inextricably linked to the highest, most extraordinary and eternal, in the same way that he emphasizes the inseparable polarities of "Unity in Variety" (CW 1:27), "Each and All" (CW 9:14-15), macrocosm and microcosm, which together make the whole; or as he writes in "Compensation," "the universe is represented in every one of its particles" (CW 2:59). ${ }^{22}$ Particularity for Emerson never exists only in and for itself, isolated from the whole, but represents or expresses something higher than itself; nor does this link with the whole detract from the individuality or intrinsic value of the particular. Joseph Urbas describes this "synthesis": "Emerson has a firm metaphysical commitment to the Real [the universal] that does not mean depreciating the 'lower' realms of our variegated existence." ${ }^{, 23}$ Rather, Emerson repeatedly expresses a monistic, panentheistic balance of unity and particularity which somewhat paradoxically upholds the integrity of both. This point is important as detranscendentalists have occasionally accused Emerson's philosophy of violently subjugating particularity into a foreign whole. George Kateb laments: "The particular thing ... is a mere part of the All; it has no meaning in itself. ... The world suffers a great reduction by this attempted elevation. ... Everything in this world is denied intrinsic or self-sufficient value." ${ }^{, 24}$ This radically particularist interpretation misses the significance of Emerson's hen kai pan as a philosophy of interconnected particularity and a monistic synthesis or balance between unity and difference which is conceived as doing justice to both poles. For Emerson, particularity has an intimate relation with the whole, just as the instant is united to the eternal.

The epiphanic and spiritual value of the present instant is the subject of the second part of Emerson's fascinating essay "Works and Days," in which he celebrates "the deep today":

It was the deep to-day which all men scorn; the rich poverty, which men hate; the populous, all-loving solitude, which men quit for the tattle of towns. HE [sic] lurks, he hides, - - he who is success, reality, joy, and power. One of the illusions is that the present hour is not the critical, decisive hour. Write it on your heart that every day is 
the best day in the year. No man has learned anything rightly, until he knows that every day is Doomsday. 'Tis the old secret of the gods that they come in low disguises. [Emerson here lists the Norse, Hindu, Greek and Christian legends in which divinity visits the lowest members of society.] ... We owe to genius always the same debt, of lifting the curtain from the common, and showing us that divinities are sitting disguised in the seeming gang of gypsies and pedlers. ... Do not refuse the employment which the hour brings you, for one more ambitious. ... [A]n old French sentence says, "God works in moments" (CW 7:88-89, 90).

The deep today, inhabited already and always by the lurking gods, contains its value in itself, and not in its role as a necessary link toward some later, better date. The hour is not considered critical and decisive here because of the future-oriented tasks that will be accomplished now; rather it is significant because of the success, joy, or higher power it already contains, regardless of what we do. Far from offering an eschatological perspective, here "every day is Doomsday." There is no exhortation toward patience. The present is not part of a project, but is the accomplishment itself, as the immediate dwelling-place of divinity. Emerson continues:

And him I reckon the most learned scholar, not who can unearth for me the buried dynasties of Sesostris and Ptolemy, the Sothiac era, the Olympiads and consulships, but who can unfold the theory of this particular Wednesday. Can he uncover the ligaments concealed from all but piety, which attach the dull men and things we know to the First Cause? These passing fifteen minutes, men think, are time, not eternity; are low and subaltern, are but hope or memory, that is, the way to or the way from welfare, but not welfare. Can he show their tie? That interpreter shall guide us from a menial and eleemosynary existence into riches and stability (CW 7:91)

Emerson dismisses hope and memory in the interest of the simple experience of the present instant. The day's isolation from linear temporality, and relation only to the higher power, has an analogue in the self which is reliant not on custom or tradition but only on the inner divine light, celebrated in "Self-Reliance." Just below this passage, Emerson makes the analogy between the day and the self explicit: "you must be a day yourself, and not interrogate it like a college professor" (CW 7:91). Indeed, the end of "Works and Days" recalls the earlier essay: "There are people ... who have self-existence and self-help; who are suffered to be themselves in society; who are great in the present ... What he is will appear in every gesture and syllable. In this way the moment and the character are one" (CW 7:93). The self and the day fuse when both are perfectly self-reliant. Both essays encourage the reader to let go of past and future, to dismiss memories and plans, and to trust one's spontaneous thoughts and actions in the present moment. The essay "Self-Reliance" describes the relation between divinity and the heightened instant thus: "Whenever a mind is simple, and receives a divine wisdom, old things pass away,- - means, teachers, texts, temples fall; it lives now and absorbs past and future into the present hour" (CW 2:38). The earlier version of this passage, from the lecture "Duty" (1839), is even more explicit about the spiritual temporality of the isolated moment: "[the soul] lives now and not from the past. The present hour is the descending God, and all things obey. All the past exists to it as subordinate. All the future is contained in it" (EL 3:141). The present contains all time as though it were itself a seed of eternity. This atemporal instant is "above time," as Emerson writes in "Self-Reliance": 
These roses under my window make no reference to former roses or to better ones; they are for what they are; they exist with God to-day. There is no time to them. There is simply the rose; it is perfect in every moment of its existence. Before a leafbud has burst, its whole life acts; in the full-blown flower, there is no more; in the leafless root there is no less. Its nature is satisfied, and it satisfies nature, in all moments alike. But man postpones or remembers; he does not live in the present, but with reverted eye laments the past, or, heedless of the riches that surround him, stands on tiptoe to foresee the future. He cannot be happy and strong until he too lives with nature in the present, above time (CW 2:38-39).

The rose is not oriented toward the past or the future but exists outside of time, above it, in a timeless present - an experience of the present that it behooves humanity to imitate. ${ }^{25}$ Emerson uses the eloquent term "the deep present" in the first version of this passage (JMN 7:226 [1839]). The moral valorization of the isolated instant is echoed in "Experience": "To finish the moment, to find the journey's end in every step of the road, to live the greatest number of good hours, is wisdom. ... Since our office is with moments, let us husband them. Five minutes of today are worth as much to me, as five minutes in the next millennium. Let us be poised, and wise, and our own, today" (CW 3:35). Emerson's descriptions of the value of the heightened moment specifically preclude an awareness of or orientation toward the future, but rather sever it from any linear temporality.

We thus have on one hand a progressive, forward-looking time, a linear advance of events whose identity is defined by their place in a chronological ascension, and on the other hand we have an instantaneous and timeless present experience whose eyes are closed to any other moment but its own, but open onto eternity. Eschatological time contrasts with epiphanic time. In human lived experience, these take the form of a constant thought of what is (hopefully) to come, and an oblivion of past or future. Perhaps this apparently dissonant overlap is ultimately unproblematic: perhaps the larger view or circle encompassing both could be understood as a linear, teleological time punctuated by a series of timeless moments each advancing toward a higher future. But this possible solution calls up a number of questions. On a phenomenological level, it would be difficult to both consciously anticipate and forget the future. This idea would also imply that the thickened instant of today is somehow better than that of yesterday, and worse than that of tomorrow, which Emerson explicitly denies. And it creates an ambiguity as to whether eternity is only final - after time - or present at every moment - above time. There seems to be a contradiction; we are obliged to recognize that it is difficult to coordinate the two.

\section{James Guthrie, in his book Above Time: Emerson's and Thoreau's Temporal} Revolutions discusses each of the two temporalities, but does not spend long on their relations. He claims that the two coincide unproblematically, by arguing that time progresses via timeless moments; without them, there would be no progress. Speaking of the heightened present moments, he writes: "Absent these insights into eternity, however, Emerson thought time did not 'move,' or advance toward the condition of unity and perfection posited by his progressive and developmental teleology." ${ }^{26}$ That is, the fact of instantaneous timelessness allows linear time to move forward. This is conceivably possible, and would constitute one way of making sense of the situation, but it is an affirmation without real substantiation in the texts, and ultimately it maintains rather than explains the paradox.

Stanley Cavell also evokes this imbrication of temporalities in his Conditions Handsome and Unhandsome: The Constitution of Emersonian Perfectionism, and, one might 
say, ratchets up the paradox even more tightly. ${ }^{27}$ Despite the future orientation inherent in Cavell's concept of perfectionism of the self (his term "perfectionism" may arguably be understood to be akin to the progressive temporality), he states that every moment, day or state is equally valuable. ${ }^{28}$ He speaks of "Emerson's sense ... that each state of the self is, so to speak, final: each state constitutes a world (a circle, Emerson says) and it is one each one also desires ... On such a picture of the self one could say both that significance is always deferred and equally that it is never deferred.", "'Significance" would seem to be in this context analogous to Emerson's various terms for that which is to come, or alternatively that which already invests the everyday - thus a secularized version of what he calls, in the above citations, "vast-flowing vigor," "unbounded substance," "the ill-concealed deity," "some new infinitude," "the highest spiritual cause," that is, the divine principle.) This significant entity is both never and always deferred. Rather than tackling the contradiction, Cavell rides it. Commenting on Emerson's quite progressivist phrase from "History," (CW 2:5) the "unattained but attainable self," Cavell writes: "our position is always (already) that of an attained self ... the self is always attained, as well as to be attained ... That one way or the other a side of the self is in negation - either the attainable negates the attained or vice versa - is the implication I drew earlier in saying that each state of the self is final." ${ }^{30}$ Cavell here recognizes that the two are contradictory (they negate each other) but tightens rather than clarifies the paradox by declaring the simple simultaneity of opposites. He goes on to say that the idea that every state of the self is final could be a useful backstop against the risk of perfectionism sounding metaphysical due to its teleological overtones:

[W]hy do I call it perfectionism, incurring or toying with metaphysical suggestions I say I want no part of? Most significant is the suggestion of a state, the same for all, at which the self is to arrive, a fixed place at which it is destined to come home to itself. Is it worth this risk of suggestion to be able to say, as if blocking the metaphysical with a paradox, that each state of the self is final? ... I might answer this by saying that it is a mission of Emersonian Perfectionism precisely to struggle against false or debased perfectionisms....

Cavell desires to use the present and the everyday - in this case, the idea that every state of the self is final and valuable in itself - as an antidote to (teleological) metaphysics, which may be one way to explain Cavell's, but not Emerson's, paradox. However, as described earlier, for Emerson the everyday is a highly metaphysical concept. Cavell's interpretation of the present day divests it of its epiphanic quality. Cavell later attempts to bring the two temporal perspectives together by arguing that perfectibility must take place every day, in the moment, and urgently; quoting "The American Scholar" (CW 1:66), he writes:

In Emerson's way of speaking, "one day" ("Each philosopher ... has only done, [for me,] as by a delegate, what one day I can do for myself") always also means today; the life he urgently speaks for is one he forever says is not to be postponed. It is today that you are to take the self on; today that you are to awaken and consecrate yourself to culture, specifically, to domesticate it gradually, which means to bring it home, as part, now, of your everyday life. This is Perfectionism's moral urgency. ... Domestication in Emerson is the issue, or urgency, of the day, today, one among others, an achievement of the everyday, the ordinary, now, here, again, never again., 32

However, Emerson's deep today is not imbued with urgency: "Cannot we let the morning be?" ("Works and Days, CW: 7:91). Rather than enjoining us to undertake something we "are 
to" do or achieve this day, Emerson asks this Thoreauvian question. As we have seen, the value of the present hour for Emerson is not in its role as a stepping stone to any future state; this instrumentalization of the present day in the interest of perfectionism is quite different from Emerson's valorization of timeless present moments in and for themselves, referring to neither past nor future. Emerson's everyday is the opposite of urgent: simple acceptance of what is. There is no further perfecting possible. "There is simply the rose ... Its nature is satisfied" (CW 2:38, 39). Cavell shifts the emphasis of the instant's importance from being to becoming, making the everyday serve the realization of some larger project, something not yet manifested: the gradual domestication of culture, "the higher or further self," "the aspiration to the human," "finding a home for humanity" - all part of the "overcoming or overtaking of skepticism [which] must constitute a revolution that is a domestication for philosophy." 33 Inserting the everyday into a long-term project of perfectionism of the self or the overcoming of skepticism would be another way of attempting to make sense of Emerson's paradox, not unlike Guthrie's in that it also gives priority to progressive time. But it does not do justice to Emerson's striking intuition of the truly timeless everyday.

One might note in passing that Cavell's take on Emerson's views of time is a good example of his critical approach of riffing on his authors, that is, using them as a jumping off point for his own philosophical reflections, an approach that is highly evocative and stimulating but not always precise or closely attentive to the original text. ${ }^{34}$ His avoidance of Emerson's many metonyms for the divine, and his focus on the experience and evolution of the self in isolation rather than as representative for, expressive of, or reliant upon something higher, illustrate his detranscendentalizing tendency toward conceptual reduction and the draining of the metaphysical from Emerson's thought. ${ }^{35}$ Cavell turned to Emerson for aid in his lifelong grappling with skepticism, an agonistic embrace of an entity he can neither definitively throttle nor release, because he defines philosophy in relation to it: "philosophy's essential business has become the response to skepticism."36 The everyday, a concept derived partly from Emerson, was enlisted in this effort; philosophy's task is understood as both "the recovery of the (my) ordinary (voice) from skepticism" and "the overcoming, or say critique, of metaphysics." ${ }^{37}$ Because Cavell is concerned above all with skepticism, he focuses on Emerson's infrequent skeptical passages and sees in him both a fellow skeptic and an ally whose valorization of the everyday might aid in the "response" to skepticism. More precisely, Cavell projects his own profound ontological skepticism about foundations onto Emerson's passing moments of epistemological skepticism about senses and illusions. ${ }^{38}$ Emerson indeed has rare skeptical moments, especially in "Experience," but as several scholars have shown, his fundamental philosophy (even in that essay) is not skeptical but one of strong spiritual and metaphysical affirmation. ${ }^{39}$ What Cavell writes about Dewey's interpretation of Emerson could as easily be said of his own: it "reads like a poignant wish to find something in Emerson's achievement that he could put to use in his own work." more Emersonian recovery of the ordinary from skepticism would be to return it to metaphysics.

How then should we understand or clarify the coexistence of Emerson's two ways of viewing temporality? It seems difficult to draw a larger circle around them. Rather than trying to embrace or embroider the paradox or, on the other hand, to reduce it to one of the perspectives, we should simply recognize this situation as an unresolved tension within Emerson's thought, and try to contextualize it. This is not the only inconsistency Emerson deals us; witness for example his lifelong tangle of fate and freedom. Emerson's juxtaposed, contrasting views of time seem to be an example of an unabsorbable, uncircumscribable contradiction. Although a paradox or simple contradiction may be unresolvable, it need not 
be abandoned as such, and may be clarified to a degree through contextualization. To make better sense of this situation it is necessary to look more closely at Emerson's metaphysics. In many ways, these two views of time correspond to two contrasting metaphysical perspectives that Emerson adopts simultaneously throughout his life, to differing and fluctuating degrees, and often in the same writings: dualism and immanentism (or more precisely, panentheism). ${ }^{41}$ Emerson is generally a panentheist; his occasional expressions of dualism create slight incongruities within his fundamental monistic metaphysics of immanence. ${ }^{42}$ Note that immanence is not pantheistic monism, which posits that the divine and the world are identical; Emerson views the divine power as infusing and inhabiting the world but remaining superior to it. Emerson's immanentism - influenced by Wordsworth, Goethe, Swedenborg, Boehme, Cudworth, the classical Neoplatonists, and others, as well as the Protestant enthusiastic tradition of divine inspiration - is on view almost everywhere in his writings, in his many and varied assertions of the omnipresence of dynamic, divine energy as well as the unity and relatedness of humans and cosmos. It witnesses the eternal flux of being's tide circulating throughout all of existence and humanity: "an instantaneous instreaming causing power" (CW 1:43). ${ }^{43}$ In innumerable passages, the immanence of the sacred force in nature is directly perceived with the senses, revealing the unity between the perceiving subject, the world and the divine. The temporality of the everlasting now has its source in Emerson's metaphysics of immanence, and invokes the experience of an "instantaneous" and immediate relation or identity between the present and the eternal.

On the other hand, the progressive temporality is rooted in Emerson's idealist and Christian dualism, distinguishing between the lower and the higher, between the here and the hereafter, between the temporal and the eternal worlds, and posits a linear ascent from one to the other. Emerson's dualism is influenced by his Protestant past and environment as well as his readings in German idealism, Plato and the Vedantic tradition. It manifests itself in occasional passages that emphasize a split or a felt absence of relation between self and world or spirit and nature, as well as in his infrequent idealist terminology of subject/object, and in various moments of subjective idealist skepticism as to the reality of the external world. He expresses such a division between humanity and nature as well as a doubt of sense perceptions in several passages in the "Idealism" section of Nature - passages which do not cohere with the general immanentism of that book - and in "Experience," for example. In terms of temporality, this dualism is conveyed in the idea of the "not yet": the awareness of a difference between present and future experience, the idea that this present state is inferior to the future one but is progressing toward it, and the feeling that we await, expect and hope for but do not immediately experience that coming grandeur, that "vast-flowing vigor" toward which our present day "hint[s]" (CW 3:42). Emerson thus variously maintains both dualistic and immanentist perspectives toward time. In a similar vein (though a somewhat different context), Russell B. Goodman writes: "the dualism (of dream and reality) that Emerson seems to embrace is countered by an equally strong sense that this world, the world we experience, contains all the divinity we shall ever need or find." ${ }^{44}$ For Emerson, it seems, the highest being is both, or alternately, ever to come and perpetually present.

This double metaphysical background may help us explain some of the slight inconsistencies that we find in Emerson's thinking about time. Although the rose exists in the timeless instant "in all moments alike," Emerson says occasionally that we humans experience the eternal epiphanic moments only intermittently, or even rarely. For example, in "Montaigne," Emerson writes: "Reason, the prized reality, the Law, is apprehended now and then for a serene and profound moment amidst the hubbub of cares and works which have no direct bearing on it; - is then lost, for months or years, and again found, for an interval, to be 
lost again. If we compute it in time, we may, in fifty years, have half a dozen reasonable hours" (CW 4:101). And in "The American Scholar": "the seer's hour of vision is short and rare among heavy days and months" (CW 1:58). This inconsistency regarding the frequency of such moments may possibly be explained by an incursion of Emerson's occasional dualism into his fundamental monistic immanence: a dualistic split between humanity and nature comes to inflect the immanentist temporality of heightened moments. Humans and roses experience time differently. The deep present is continuously experienced by the rose, but not by humanity; humans postpone and anticipate, remember and lament; roses do not. We live - at least frequently - in the progressive temporality, while nature lives in the eternal present moment of pure immanence. Theoretically, in a simple monism, humans and nature would operate in the same way; we would have the same uninterrupted relationship with "the prized reality, the Law" as do roses. But Emerson tells us occasionally that the epiphanic moments are seldom. The heightened experience of the everyday is not every day; these moments are grounded in the commonplace, but they are not common. This creates a dissonance between the two senses of the word "common" (ordinary and frequent): crossing the commons, Emerson has, according to some of his statements, an uncommon experience.

This imbrication of contrasting temporalities may help explain such paradoxical passages as the following: "[Man] cannot be happy and strong until he too lives with nature in the present, above time" ("Self-Reliance," CW 2:39). Oddly, the timeless present moment is said to be in the future. The first version of this passage is even more revealing of the tension between the two overlapping temporalities: "So shall Man one day live with living nature, happy \& strong in the deep present. There is no time to just men" (JMN 7:226 [1839]). We have here both the monistic experience of living in the deep present, and the dualistic projection of that better moment into the future. The deep present is not now, but "one day." Eschatological time collides with epiphanic time, and the eternal moment paradoxically takes on the optative mood. These tensions are encapsulated poignantly in the following exclamation in the journal: "Ah when! Ah how rarely! can he draw a true Aeolian note from the harp" (JMN 11: 373 [1851]). ${ }^{45}$ The wind harp is a model for the self traversed by the immanent divine forces, resulting in song or poetry. Theoretically true aeolian notes should not be rare, as the wind blows almost continuously through a wind harp, the quintessential figure for the ever-present immanence of the divine breath in nature. The wind is an everyday and common phenomenon. But Emerson feels here that it seldom visits his or humanity's harp, and this anxious experience of spotty immanence contrasts sharply with the continuous and reposed immanence of the rose.

Emerson thus juxtaposes two contrasting temporalities, a monistic valorization of the heightened present moment, and a dualistic orientation toward a better future moment. The two do not cohere easily, and it seems difficult to draw a larger circle around the opposition. His two temporalities coexist with a gentle tension, giving rise to paradoxes and contradictions. Full consistency would surely be too much to ask, and we would be only chasing hobgoblins. Rather, Emerson's views of time are fluctuating, creating a poetic complexity.

\footnotetext{
${ }^{1}$ The Collected Works of Ralph Waldo Emerson, ed. Alfred R. Ferguson and Joseph Slater et al., 7 vols. to date (Cambridge: Harvard UP, 1971-), 3:42; hereafter cited parenthetically as CW, with volume and page number.

2 The term was first used by Lawrence Buell ("The Emerson Industry in the 1980s: A Survey of Trends and Achievements," ESQ: A Journal of the American Renaissance 30:2 [1984], 117-136, 120), and was taken up in the title of Michael Lopez's article "De-transcendentalizing Emerson,” ESQ 34:1-2 (1988), 77-139.
} 
${ }^{3}$ For a full discussion of the "detranscendentalizing" critical approach, see Daniel S. Malachuk's introduction to this issue of ESQ, "Re-Transcendentalizing the Transcendentalists," and his "Emerson's Politics,

Retranscendentalized," in A Political Companion to Emerson, eds. Alan M. Levine and Daniel S. Malachuk (Lexington: UP of Kentucky, 2011), 265-304; 265-273.

${ }^{4}$ George Kateb, Emerson and Self-Reliance (Thousand Oaks: Sage Publications, 1995), 81.

${ }^{5}$ Lawrence Buell, Emerson (Cambridge: Harvard UP, 2003), 158, 160; see "Religious Radicalisms," 158-198.

${ }^{6}$ David M. Robinson, "Emerson and Religion," in A Historical Guide to Ralph Waldo Emerson, ed. Joel

Myerson (Oxford: Oxford UP, 2000), 151-178; Robinson, "Emerson: Religion after Transcendentalism," The Concord Saunterer 11 (2003): 30-37; Yves Carlet, "La 'religion transcendantale': continuités et ruptures," in L'Euvre en prose de Ralph Waldo Emerson, eds. François Brunet and Anne Wicke (Paris: Armand Colin, 2003), 1-18; Daniel S. Malachuk, "Transcendentalism, Perfectionism, and Walden," The Concord Saunterer New Series 12/13 (2004-05): 283-303.

${ }^{7}$ Randy L. Friedman, "Traditions of Pragmatism and the Myth of the Emersonian Democrat," Transactions of the Charles S. Peirce Society 43:1 (2007): 154-84; 155. "Religious Self-Reliance," The Pluralist 7:1 (2012): 27-53.

${ }^{8}$ Robert Milder, "From Emerson to Edwards," The New England Quarterly 80:1 (2007): 96-133; "Emerson and the Fortunes of Godless Religion," The New England Quarterly 87:4 (2014): 573-624.

${ }^{9}$ Neal Dolan, Emerson's Liberalism (Madison: U Wisconsin P, 2009).

${ }^{10}$ Mark S. Cladis, "Religion, Democracy, and Virtue: Emerson and the Journey's End," Religion and Literature, 41:1 (2009): 49-82; on Kateb's attempt to secularize Emerson, see 51-54. Shira Wolosky, "Emerson's Figural Religion: From Poetics to Politics," Religion and Literature, 41:1 (2009): 25-48.

${ }^{11}$ Russell B. Goodman, "Paths of Coherence through Emerson's Philosophy: The Case of 'Nominalist and Realist" " in The Other Emerson, ed. Branka Arsić and Cary Wolfe (Minneapolis: U of Minnesota P, 2010), 4158. See also Goodman, American Philosophy and the Romantic Tradition (Cambridge: Cambridge UP, 1990), 34-57; "The Colors of the Spirit: Emerson and Thoreau on Nature and the Self," in Nature in American Philosophy, ed. Jean De Groot (Washington, DC: Catholic University of America Press, 2004), 1-18.

${ }^{12}$ Malachuk, "Emerson's Politics, Retranscendentalized"; Two Cities: The Political Thought of American Transcendentalism (Lawrence: UP of Kansas, 2016).

${ }^{13}$ Alan M. Levine, "Skeptical Triangle? A Comparison of the Political Thought of Emerson, Nietzche and Montaigne," in A Political Companion to Emerson, eds. Alan M. Levine and Daniel S. Malachuk (Lexington: UP of Kentucky, 2011), 223-264.

${ }^{14}$ Samantha Harvey, Transatlantic Transcendentalism: Coleridge, Emerson and Nature (Edinburgh: Edinburgh UP, 2013).

${ }^{15}$ Danielle Follett, "The Tension between Immanence and Dualism in Coleridge and Emerson," in Romanticism and Philosophy: Thinking with Literature, eds. Thomas Constantinesco and Sophie Musitelli (London: Routledge, 2015), 209-221.

${ }^{16}$ Joseph Urbas, “'True Romance': Emerson's Realism,” Southwest Philosophy Review 25:2 (2009): 113-47; “Cavell's 'Moral Perfectionism' or Emerson's 'Moral Sentiment'?” European Journal of Pragmatism and American Philosophy 2:2 (2010): 41-53; “'Bi-Polar' Emerson: 'Nominalist and Realist,” The Pluralist 8:2 (2013): 78-105; Emerson's Metaphysics: A Song of Laws and Causes (Lanham: Lexington Books, 2016). 17 "Duty," in The Early Lectures of Ralph Waldo Emerson, ed. Stephen E. Whicher, Robert E. Spiller, and Wallace E. Williams, 3 vols. (Cambridge: Harvard UP, 1959-72), 3:141; hereafter cited parenthetically as EL, with volume and page number.

${ }^{18}$ Neal Dolan, "History," in Ralph Waldo Emerson in Context, ed. Wesley T. Mott (Cambridge: Cambridge UP, 2014), 109-117, 112. For a discussion of Emerson's progressive time and contemporaneous scientific interpretations of the temporality of evolution, see James Guthrie, Above Time: Emerson's and Thoreau's Temporal Revolutions (Columbia: U of Missouri P, 2001), 25-45.

19 "The Naturalist": "An everlasting Now reigns in Nature that produces on our bushes the selfsame Rose which charmed the Roman and the Chaldaean" (EL 1:71). See also "Works and Days" (CW 7:88). Thomas Carlyle also uses the term "an everlasting Now" in Sartor Sartorus, eds. Mark Engel and Rodger L. Tarr (Berkeley: U California P, 2000), 192.

${ }^{20}$ On the temporality of the eternal present, see Guthrie, Above Time, 92-101.

${ }^{21}$ Stanley Cavell, Emerson's Transcendental Etudes (Stanford: Stanford UP, 2003), 37.

${ }^{22}$ For "each and all," see also The Journals and Miscellaneous Notebooks of Ralph Waldo Emerson, ed. William H. Gilman, Ralph H. Orth, et al., 16 vols. (Cambridge: Harvard UP, 1960-82), 5:128; hereafter cited parenthetically as JMN, with volume and page number. In this passage Emerson is translating Goethe, and the editors also remark on Ralph Cudworth's use of the term in The True Intellectual System of the Universe. For a good discussion of Emerson's "synthesis" of particularity and unity, see Urbas, "Bi-Polar Emerson," 85-86. ${ }^{23}$ Urbas, "Bi-Polar Emerson," 83, 85. 
${ }^{24}$ Kateb, Emerson and Self-Reliance, 66, 70.

${ }^{25}$ For Guthrie's readings of this passage, which provides the title of his book, see Above Time, 2-3, 97-98.

${ }^{26}$ Guthrie, Above Time, 98 . Guthrie also suggests that because humanity is unseated from the endpoint of evolution, as stated in "Fate," Emerson valued the particular moment more highly (45).

${ }^{27}$ Stanley Cavell, Conditions Handsome and Unhandsome: The Constitution of Emersonian Perfectionism (Chicago: U Chicago P, 1990).

${ }^{28}$ Joseph Urbas ("Cavell's 'Moral Perfectionism"') argues convincingly that Cavell's theory of perfectionism is inconsistent with Emerson's philosophy.

${ }^{29}$ Cavell, Conditions Handsome and Unhandsome, 3-4.

${ }^{30}$ Cavell, Conditions Handsome and Unhandsome, 12.

${ }^{31}$ Cavell, Conditions Handsome and Unhandsome, 13.

${ }^{32}$ Cavell, Conditions Handsome and Unhandsome, 54-5, 61. Cavell omits the "for me" in brackets.

${ }^{33}$ Cavell, Conditions Handsome and Unhandsome, 54, 56.

${ }^{34}$ See Joseph Urbas, "How Close a Reader of Emerson Is Stanley Cavell?" The Journal of Speculative

Philosophy 31:4 (2017): 557-74; as well as his Emerson's Metaphysics, 24-25.

${ }^{35}$ For a critique of Cavell's interpretation of Emerson's self as self-contained and metaphysically ungrounded, see Urbas, "Cavell's 'Moral Perfectionism."”

${ }^{36}$ Cavell, Emerson's Transcendental Etudes, 59.

${ }^{37}$ Cavell, Emerson's Transcendental Etudes, 59.

${ }^{38}$ Joseph Urbas notes that Emerson recorded Joseph-Marie Degérando's statement in his journal: "it was of the external world and never of metaphysical truths that he was skeptical saith DeG. It was Idealism which he maintained," qtd in Urbas, Emerson's Metaphysics, 75.

${ }^{39}$ Levine, "Skeptical Triangle?" especially 246-249; Malachuk, "Emerson's Politics," 288-295; Urbas, "Bi-

Polar Emerson," "Cavell's 'Moral Perfectionism,"” and Emerson's Metaphysics, which argues that Emerson's causationism is a response to Hume's skepticism.

${ }^{40}$ Cavell, Conditions Handsome and Unhandsome, 16.

${ }^{41}$ On panentheism, see Harvey, Transatlantic Transcendentalism, 110-116.

${ }^{42}$ For a more elaborate discussion of Emerson's metaphysical tensions, see Follett, "The Tension between Immanence and Dualism."

${ }^{43}$ On the "causing power" and the importance of causality in Emerson's metaphysics, see Urbas, Emerson's Metaphysics.

${ }^{44}$ Goodman, American Philosophy and the Romantic Tradition, 42.

${ }^{45}$ This passage recalls Emerson's poem, "Days," where the succession of days bearing gifts is colored in a negative light as the poet experiences shame or guilt for not living up to their promise (CW 9:427) In this context, Guthrie speaks of Emerson's "temporal guilt" and "diurnal anxiety" (Above Time, 115). 